\title{
Research on the Influence of Teaching Leadership on Teaching Quality
}

\author{
Xiaowei Liu* and Liang Chen \\ School of Economics and Management, Zhejiang University of Water Resources and Electric Power, \\ 310018 Hangzhou, China
}

\begin{abstract}
Teachers' teaching leadership will afflict the quality of teaching. Governed by the straightforward theory of leadership power, construct the behaviors system of teachers' teaching leadership. Through the questionnaire survey, we can assess the influence of teachers' teaching leadership and its behaviors system on the evaluation of curriculum teaching quality. Research demonstrates that teachers' professional teaching leadership and inspirational teaching leadership have a material effect on instructing quality evaluation. Teachers' teaching methods and ideological along with honorable behaviors have a sizeable impact on the evaluation of teaching quality.
\end{abstract}

\section{Introduction}

Colleges and universities are committed as part of cultivating future talents. Teaching activities form an integral part of college work. Improving the quality of teaching represents one of the crucial objectives of teaching management activities.

In the past, research on teaching quality mainly focused on the monitoring system, evaluation method, evaluation system, guarantee system, customer satisfaction evaluation and teaching leadership. [1-2] Among them, research on teaching leadership is mainly carried out from the aspects of vice-chancellor's teaching leadership model, investigation, relationship with teaching quality, and teacher's teaching leadership model and promotion. [3] In the vice-chancellor's teaching leadership activities, teachers' teaching behaviors are a function of organizing teaching activities and establishing a learning community. Then through the teacher's teaching behaviors to affect students' learning behaviors to affect the quality of curriculum teaching. [4]

At present, there is a lack of quantitative studies on the relationship between teachers' teaching leadership and teaching quality. Teachers are the exporters of curriculum know people ledge or the organizers and leaders of classroom teaching activities. Teachers formulate and implement specific teaching behaviors to influence students' learning behaviors, achievements and teaching quality, and play an important role in instructing leadership activities between teachers and students. [5]

* Corresponding author: 1828985956@qq.com 


\section{Related concepts}

Power is an essential element of leaders' leading activities. The power base includes five aspects, namely, the power of expertise, the power of inspiration, the power of legality, the power of reward and the power of coercion. Leadership lies in the position of the leader to act on the behaviors and psychology of the people led. Teaching leadership is the opportunity of leaders (vice-chancellors, teachers and other subjects) to impact the people led (teachers, students and other subjects) in teaching activities. Acting in accordance with the leadership situation, interactive subjects of teaching leadership activities can be subdivided into school leaders and teachers in teaching management, and teachers and students in teaching implementation.

Based on the connotation of power base, this study decomposes teachers' teaching leadership into 15 observable and available teaching leadership behaviors, and each teaching leadership corresponds to three teaching leadership behaviors. The research object is teachers who are the leaders in the teaching activities and students who are mapped. Through the questionnaire survey, students' evaluation of teachers' teaching behaviors and teaching quality is understood. This paper handles the influence of teachers' teaching leadership and teaching behaviors on teaching quality evaluation.

Five power bases and teaching leadership. The corresponding relationship of 15 teaching leadership behaviors is presented in the table below.

Table 1. Power base, leadership and teaching leadership behavior.

\begin{tabular}{|c|c|c|c|c|c|}
\hline $\begin{array}{c}\text { Classifi } \\
\text { cation }\end{array}$ & $\begin{array}{c}\text { Power } \\
\text { base }\end{array}$ & $\begin{array}{c}\text { Teaching } \\
\text { leadership }\end{array}$ & \multicolumn{2}{|c|}{ Teaching leadership behavior } \\
\hline 1 & $\begin{array}{c}\text { Specialty } \\
\text { power }\end{array}$ & Expertise leadership & $\begin{array}{c}\text { professional } \\
\text { knowpeople ledge }\end{array}$ & $\begin{array}{c}\text { Teaching } \\
\text { method }\end{array}$ & $\begin{array}{c}\text { Scientific } \\
\text { research level }\end{array}$ \\
\hline 2 & $\begin{array}{c}\text { Impel } \\
\text { power }\end{array}$ & $\begin{array}{c}\text { Charismatic } \\
\text { leadership }\end{array}$ & $\begin{array}{c}\text { Personality } \\
\text { characteristics }\end{array}$ & $\begin{array}{c}\text { Ideology and } \\
\text { morality }\end{array}$ & $\begin{array}{c}\text { Teaching } \\
\text { attitude }\end{array}$ \\
\hline 3 & $\begin{array}{c}\text { Legitimat } \\
\text { e power }\end{array}$ & Statutory leadership & $\begin{array}{c}\text { Attendance by roll } \\
\text { call }\end{array}$ & Assignment & $\begin{array}{c}\text { Classroom } \\
\text { questioning }\end{array}$ \\
\hline 4 & $\begin{array}{c}\text { Reward } \\
\text { power }\end{array}$ & $\begin{array}{c}\text { Rewarding } \\
\text { leadership }\end{array}$ & Verbal Praise & $\begin{array}{c}\text { Guide the } \\
\text { competition }\end{array}$ & $\begin{array}{c}\text { Give bonus } \\
\text { points }\end{array}$ \\
\hline 5 & $\begin{array}{c}\text { Coercive } \\
\text { power }\end{array}$ & $\begin{array}{c}\text { Mandatory } \\
\text { leadership }\end{array}$ & Punish students & $\begin{array}{c}\text { Correct } \\
\text { homework }\end{array}$ & $\begin{array}{c}\text { Truthful } \\
\text { attendance }\end{array}$ \\
\hline
\end{tabular}

\section{Questionnaire description}

This research picks up the students at the school of economics and management of Zhejiang University of Water Resources and Electric Power as the survey object, and the total number of students is 153. Each student scores the teaching behaviors of teachers in four courses (financial accounting, production management, staff recruitment and Market Research) on 15 aspects, and evaluates the teaching quality based on their own learning experience.

Each questionnaire comprises three parts. The main question is multiple-choice questions, using a five point scoring system. 1 point means very disagree, or very not in line with the reality; 5 points mean very agreeable, or vary in line with reality. 


\section{Data analysis}

Data analysis is composed of four parts. The first part is the analysis of the differences in teaching quality evaluation of different teachers. The second part represents the difference analysis of teaching leadership of diverse teachers. The third part is the analysis of the influence of teachers' teaching leadership on the quality of curriculum teaching. The fourth part is the analysis of the influence of teachers' teaching leadership behaviors on teaching quality.

\subsection{Analysis of the differences of teaching quality evaluation of different teachers}

First of all, in the description of teaching quality evaluation, the average score of financial accounting teachers is 4.35 , the average score of production management teachers is 4.09 , the average score of staff recruitment teachers is 3.59, and the average score of market research teachers is 4.74 .

Furthermore, in the analysis of variance of teachers' teaching quality evaluation score, the test of variance $\mathrm{f}=12.805$, the corresponding significance is 0.000 , less than the significance level of 0.05 , so there is a significant difference between at least one teacher and another teacher's teaching quality evaluation score.

What is more, through multiple comparison of teaching quality evaluation scores, it is found that there are significant differences in teaching quality evaluation scores among market research teachers, production management teachers and staff recruitment teachers, and significant differences in teaching quality evaluation scores between financial accounting teachers and staff recruitment teachers.

\subsection{Analysis on the differences of teaching leadership among different teachers}

The evaluation of teachers' teaching leadership is the sum of students' evaluation of teachers' teaching leadership behaviors in the classroom. There are 15 teaching leadership behaviors. Each of which has 5 points, and the aggregate score of teaching leadership is 75 points.

Single sample analysis of variance was utilized. After emptying the data, there are the following analysis results.

To begin with, in the description of teachers' teaching leadership score, the average teaching leadership score of financial accounting teachers is 59.64, the average teaching leadership score of production management teachers is 59.50, the average teaching leadership score of staff recruitment teachers is 52.67, and the average teaching leadership score of market research teachers is 64.02 .

Also, in the analysis of variance of teachers' teaching leadership score, the test of variance $f=10.642$, the corresponding significance is 0.000 , less than the significance level of 0.05 , so there is a significant difference between at least one teacher and another teacher's teaching leadership score.

Last but not least, through multiple comparisons of teaching leadership scores, it is found that there are significant differences in teaching leadership scores among staff recruitment teachers, financial accounting teachers, production management teachers and market research teachers, while there is no significant difference in teaching leadership scores among financial accounting teachers, production management teachers and market research teachers. 


\subsection{Regression analyses of teachers' teaching leadership and teaching quality evaluation score}

In order to understand the impact of teaching leadership on teaching quality evaluation and its degree, teaching leadership is divided into five aspects: professional leadership, charismatic leadership, statutory leadership, rewarding leadership and mandatory leadership. Each aspect of leadership corresponds to three teaching behaviors. According to students' scores on teaching behaviors, five aspects of teaching leadership scores are obtained, and the consequences are as follows through regression analysis. This paper studies the impact of teaching leadership on teaching quality evaluation.

Multiple linear regression was utilized for analysis, with expert leadership, charismatic leadership, statutory leadership, rewarding leadership and mandatory leadership as independent variables, and teaching quality evaluation as a dependent variable. The analysis results are approved as follows.

In the case of model fitting, the modified resolvable coefficient (adjusted R Square) is 0.660 , and the explanatory power of the model is widespread. In the analysis of variance, the test $\mathrm{p}$ value of the model is 0.000 , less than 0.05 , and the whole model is very hefty. Based on the regression analysis with teaching quality evaluation as the dependent variable, the expression of the model is: teaching quality evaluation $=-0.065+0.173 *$ professional leadership $+0.165 *$ charismatic leadership $-0.001 *$ statutory leadership $+0.017 *$ rewarding leadership - $0.004 *$ mandatory leadership.

Among them, there are three variables (statutory leadership, rewarding leadership and mandatory Leadership) with significant $\mathrm{p}$ value greater than 0.05 , and the coefficient is not significant. The variables with insignificant significance are removed in turning for further analysis. After eliminating the three variables of statutory leadership, mandatory leadership and rewarding leadership, and doing three regressions again, the final results are reproduced below.

In the case of model fitting, the modified resolvable coefficient (adjusted R Square) is 0.666, and the explanatory power of the model is greater than that at the beginning. In the analysis of variance, the test p value of the model is 0.000 , less than 0.05 , and the restored model is very momentous. Acting in accordance with the analysis results, the expression of the model is: teaching quality evaluation $=-0.059+0.174 *$ professional leadership + $0.173 *$ charismatic leadership.

According to the regression analysis, we can see that professional leadership and charismatic leadership have a quantifiable effect in teaching quality evaluation. Among them, each branch of specialized leadership increased the score of teaching quality evaluation by 0.174 , and each branch of charismatic leadership increased the score of teaching quality evaluation by 0.173 . However, statutory leadership, mandatory leadership and rewarding leadership have no weighty impact on the scope of teaching quality evaluation.

\subsection{Regression analyses of teachers' teaching behavior and teaching quality evaluation score}

As certified leadership and charismatic leadership have a major impact on teaching quality evaluation, this paper focuses on the analysis of the impact of six teaching behaviors correspond with the two leadership on teaching quality evaluation. Regression analysis serves to study the relationship between teaching behaviors and teaching quality evaluation. After inserting the data, the analysis results are demonstrated below.

In the case of model fitting, the modified resolvable coefficient (adjusted R Square) is 0.669 , and the explanatory power of the model is vague. In the analysis of variance, the test 
p value of the model is 0.000 , less than 0.05 , and the intact model is very sizable. According to the analysis results, the expression of the model is: teaching quality evaluation $=0.137+0.105 *$ personality characteristics $+0.268 *$ ideological and moral $0.116 *$ teaching attitude $+0.150 *$ professional know people ledge $+0.274 *$ teaching methods $+0.086 *$ scientific research ability.

Among them, significant $\mathrm{p}$ value of the four variables (research ability, personality characteristics, teaching attitude and specialized know people ledge) was greater than 0.05 , and the coefficient was not significant. After removing the four variables and making four regression analysis again, the following final results are obtained

In the case of model fitting, the modified resolvable coefficient (adjusted R Square) is 0.651 , and the explanatory power of the model is slightly smaller than that at the beginning. In the analysis of variance, the test $P$ value of the model is 0.000 , less than 0.05 , and the entire model is very momentous. Acting in line with the analysis results, the expression of the model is: teaching quality evaluation $=0.814+0.432 *$ teaching methods $+0.425 *$ ideological and moral.

From the regression analysis, it can be seen that in the teaching behaviors of teachers, the score of teaching methods and ideological and ethical have a significant impact on the evaluation of teaching quality. Among them, the score of teaching quality evaluation increased by 0.432 points for every improvement of teaching method score, and 0.425 points for every improvement of ideological and moral score. However, scores of other teaching behaviors have no significant effect on the scores of teaching quality evaluation.

\section{Conclusions}

In terms of teaching quality evaluation scores of unconventional teachers, there are significant differences between some teachers, while there are no noteworthy differences between some teachers. On the whole, there are three levels of teaching quality evaluation: high, medium and low.

In the relationship between teaching leadership and teaching quality evaluation, executive leadership and inspirational leadership have a major impact on teaching quality evaluation. Statutory leadership, mandatory leadership and rewarding leadership have no weighty influence on the scope of teaching quality evaluation.

In the relationship between teachers' teaching behaviors and teachers' quality rating, the score of teaching methods and ideological and moral have a considerable impact on teaching quality evaluation.

In order to further enhance the teaching quality and the evaluation level of teaching quality, teachers should strengthen the level of proficient leadership and inspirational leadership and the improvement of teaching methods and their own ideological and moral level.

\section{References}

1. Huang Qiuming, Wang Zheng, Gong Bei. Research on teaching quality monitoring and evaluation system in Colleges and universities [J]. Vocational and technical education, 2003, 24 (001): 19-23

2. Hu Qiguo, Li Wei, Zhou Kaifa, et al. Research on teaching quality evaluation system of higher education based on customer satisfaction [J]. Chongqing higher education, 2009, (003): 16-19

3. Zhao Xi, Liu Jing. Research on the model of principal's teaching leadership in China [J]. Management of primary and secondary schools, 2010, (003): 10-13 
4. Zeng Jiayan, Zhao Jing. Comparison and review of four evaluation models of principals' teaching leadership in the United States [J]. Foreign primary and secondary education, 2016, (010): 34-42

5. Lai Xianghui, Zhao Jianmei. Development and verification of Leadership Effectiveness Scale for university teachers [J]. Heilongjiang Higher Education Research, 2018 (7) 